\title{
Grundtvig-studier 1951
}

udsendes på Grundtvigs fødselsdag den 8. september af det i 1947 stiftede Grundtvig-Selskab. »Grundtvig-studier« redigeres af sognepræst, dr. theol. Henning Høirup og bringer $i$ år en større dokumentarisk afhandling af redaktøren: Grundtvig $i$ 1867. En række aktstykker om Grundtvigs sindssygdom, dels fra Grundtvig-Arkivet, dels fra Kultusministeriets arkiv (bl. a. et brevskifte mellem Gunni Busck og Svend Grundtvig, Grundtvigs afskedsansøgning og hans egenhændige indberetning om gudstjenesten i Vartov Palmesøndag), meddeles som baggrund for en indgående undersøgelse af digterens omfattende produktion i sygdomsåret. Ved nye fund af et meget stort antal manuskripter, forfattede dels lige før, dels under sygdommen, kastes der lys over denne Grundtvigs alvorligste »dødsstrid«. 29 hidtil utrykte digtninge udgives fuldstændigt.

Cand. mag. Steen Johansen, forfatteren af »Bibliografi over N. F. S. Grundtvigs Skrifter«, skriver ud fra sit store kendskab til forfatterskabet en aktuel afhandling $\mathrm{Om}$ Grundtvig-Udgaver. Rektor F. Paludan-Müller bidrager med en biografisk undersøgelse: »Hvorfor kom N. F. S. Grundtvig ikke i Viborg Latinskole? I I literaturafdelingen anmelder dr. phil. Niels Moller det meget omtalte værk af Magnus Stevns: »Fra Grundtvigs Salmeværksted«, og adjunkt William Michelsen bedømmer Erik Møllers bog om Grundtvig som samtidshistoriker.

\section{Tidligere udkom:}

Grundtvig-studier 1948. Gyldendal. 116 sider.

Grundtvig-studier 1949. Gyldendal. 112 sider.

Grundtvig-studier 1950. Gyldendal. 112 sider.

I serien Skrifter udgivet af Grundtvig-Selskabet er hidtil udkommet:

I. Henning Hoirup: Grundtvigs Syn paa Tro og Erkendelse. Gyldendal 1949. 420 sider.

II. Helge Toldberg: Grundtvigs symbolverden. Gyldendal 1950. XII +356 sider.

III. Magnus Stevns: Fra Grundtvigs Salmeværksted. Udgivet af Henning Høirup og Steen Johansen. Gyldendal 1950. 132 sider. 